\title{
22. INTERSTITIAL WATER STUDIES, LEG 42A
}

\author{
Russell E. McDuff and Joris M. Gieskes, Scripps Institution of Oceanography, La Jolla, California \\ and \\ James R. Lawrence, Lamont Doherty Geological Observatory, Palisades, New York
}

\begin{abstract}
Interstitial water analyses of Sites $371,372,374,375,376,377$, and 378 are reported. Also, diffusion parameters have been measured in Sites $371,372,374$, and 376. Diffusion model predictions of chloride gradients in Sites 371 and 374 agree very well with observed data. The diffusion model is subsequently used to investigate the nature of the major cation gradients in terms of diffusion and reaction. Site 374 , especially, shows a complicated depth dependency in calcium and magnesium, implying substantial reactions in these sediments. Oxygen isotope data show little change with depth, although in Site 372 there is some sign of a slight enrichment with depth, possibly related to carbonate recrystallization processes.
\end{abstract}

\section{INTRODUCTION}

Studies of the interstitial waters collected during Leg 13 in the Mediterranean Sea showed that the presence of Messinian evaporites underlying the sediments exerts a strong influence on the chemical composition of the pore solution (Sayles et al., 1972) in addition to the effects of diagenetic processes observed in more typical sedimentary environments (Sayles and Manheim, 1975; Gieskes, 1975). This fact suggested that careful chemical study of interstitial waters obtained during Leg $42 \mathrm{~A}$ could be of immense value in furthering our understanding of pore water phenomena, particularly regarding the relative effects of diffusion and reaction on pore water concentration profiles. The gradient of a non-reactive species such as chloride, established by dissolution of evaporitic phases underlying the sediment column, can serve as an ideal test for models of diffusive transport in sediments (McDuff and Gieskes, 1976). Deviation of pore water composition from this "conservative" distribution, determined by physical processes alone, can be used to identify locations of diagenetic reactions (Kastner and Gieskes, 1976) and to estimate rates of reaction. The extensive isotopic work performed on Leg 42A material provides further important constraints on the nature of the diagenetic processes. In addition, the chemistry of the pore waters can provide important clues to the composition of evaporitic phases underlying the sediments drilled (Manheim et al., 1974). The shipboard geochemical data verified the suitability of the samples from several sites for this sort of study. The contrasting profiles of calcium, magnesium, and chloride at Site 374 were indicative of an especially interesting interplay of diffusion and reaction.
This contribution is concerned mainly with the results of the analyses of chemical composition of the interstitial waters recovered from Leg $42 \mathrm{~A}$ sites and of the measurements of physical properties (porosities, formation factors) of the bulk sediment. The discussion focuses on possible interpretations of the data from Sites 371, 372, and 374. Data from the other sites were too sparse to draw meaningful conclusions. We intend to perform further work in order to amplify the thoughts presented here.

\section{METHODS}

Interstitial waters were collected, using the routine shipboard squeezing techniques described by Manheim and Sayles (1974). Small amounts of the squeezed samples were used for shipboard measurements of salinity (refractometer), calcium, and magnesium (titrations described by Gieskes, 1974). For the analysis of alkalinity and $p \mathrm{H}, 5-10 \mathrm{ml}$ samples were titrated with $0.1 \mathrm{~N} \mathrm{HCl}$, using the potentiometric technique described by Gieskes and Rogers (1973). These titrated samples were subsequently stored in sealed polyethylene vials for our shorebased analyses of other constituents $\left(\mathrm{Na}, \mathrm{K}, \mathrm{Sr}, \mathrm{SO}_{4}, \mathrm{NH}_{4}, \mathrm{Si}\right)$. The analytical methods used for these species have been described by Gieskes (1974). We were interested in supplementing the shipboard interstitial water data at Site 374 in the interval between 360 and 390 meters, in which a sharp drop in the calcium concentration occurs. For this purpose we obtained small samples of sediment from the DSDP east coast core repository. These samples yielded as much as $2 \mathrm{ml}$ of interstitial solution on which a fairly complete chemical analysis could be made. Previously we have shown in this laboratory, with stored cores from Legs 15 and 26, that interstitial 
water data for major elements from samples squeezed immediately after recovery and samples squeezed after long-term storage agree quite well (after a minor adjustment for a slight chlorinity increase due to evaporation). On this basis, we consider the chemical analyses obtained from these stored samples representative of the original conditions.

Physical properties were measured at the DSDP core repository at Lamont in February, 1976. Formation factors were determined using a modification of the method described by Manheim and Waterman (1974). The principal change we made in this method was to use measurements on laboratory solutions of varying chloride and divalent/univalent compositions to provide the appropriate reference resistivity, rather than extracting pore solution for a direct measurement. Water contents were determined by wet weight/dry weight measurements, and porosities were calculated assuming a grain density of $2.6 \mathrm{~g} / \mathrm{cm}^{-3}$ and a solution density appropriate to the composition.

Strontium interferes with the shipboard calcium titration, approximately $80 \%$ being recovered (Tsunogai et al., 1968). In addition, Gieskes and Lawrence (1976) note an artifact in the calcium determination dependent on the $\mathrm{Mg} / \mathrm{Ca}$ ratio. The magnesium values, which are determined by difference, must also be corrected for strontium values. The shipboard data have been corrected for all these effects in the tables reported here.

To further insure against artifacts influencing the titration values due to the unusual composition of the samples, the calcium and magnesium values of some samples were spot-checked by atomic absorption spectrometry. Agreement of the two methods was satisfactory.

Oxygen isotope analyses of the interstitial waters were carried out in duplicate, using the $\mathrm{CO}_{2}$ method of Epstein and Mayeda (1953).

\section{RESULTS}

The chemical data collected on pore waters are summarized in Table 1. In addition, data from Sites 371, 372, and 374 are presented in Figures 1-3.

Data on formation factors and porosities are tabulated in Table 2.

\section{DISCUSSION}

Before proceeding it is important to note that many of the samples show evidence of slight seawater contamination during drilling. This is most easily seen in the chloride profiles, which do not increase monotonically with depth as anticipated. This is also borne out by a regression of two species whose distributions are both controlled by diffusion-samples seemingly contaminated by the seawater end member fall on the regression line as expected.

\section{DIFFUSIVE BEHAVIOR}

A significant problem in interpreting interstitial water profiles is that of distinguishing between the effects of diffusion and reaction. To do this, it is necessary to know how the diffusion coefficient varies as depth increases. Manheim and Waterman (1974) determined diffusion coefficients in DSDP cores using resistivity measurements. McDuff and Gieskes (1976) extended this approach by incorporating this type of measurement in a model for diffusive transport in deep-sea sediments. Gradients of chloride supported by dissolution of evaporites at Site 371 and 374 offer an ideal means of testing the validity of such a model.

Briefly, the equation for diffusion in one dimension can be expressed

$$
\mathrm{p} \frac{\partial \mathrm{c}}{\partial \mathrm{t}}=\frac{\partial}{\partial \mathrm{z}}\left(\mathrm{pD}_{\mathrm{b}} \frac{\partial \mathrm{c}}{\partial \mathrm{z}}\right)-\mathrm{pu} \frac{\partial \mathrm{c}}{\partial \mathrm{z}}=0 \text { at steady state }
$$

where $\mathrm{p}$ is porosity, $\mathrm{c}$ is concentration, $\mathrm{t}$ is time, $\mathrm{z}$ is the vertical spatial coordinate relative to the sediment water interface, $D_{b}$ is the bulk diffusion coefficient and $\mathrm{u}$ is the pore water velocity relative to the sediment water interface. The bulk diffusion coefficient is obtained from the diffusion coefficient in the pore water alone, $\mathrm{D}_{\mathrm{p}}$, and the formation factor, $\mathrm{F}$, the ratio of the specific resistivity of the bulk sediment to that of the pore solution, by the relationship $\mathrm{D}_{\mathrm{b}}=\mathrm{D}_{\mathrm{p}} / \mathrm{pF}$. The assumptions involved and the method of solution have been discussed in detail elsewhere (Imboden, 1975; McDuff and Gieskes, 1976).

Comparisons of the model calculations with the observed chloride data for Sites 371 and 374 are shown in Figure 4. Resistivities and porosities are those of Table 2, $D_{\mathrm{p}}$ is taken as $1.43 \times 10^{-5} \mathrm{~cm}^{2} \mathrm{sec}^{-1}$ at $13^{\circ} \mathrm{C}$ ( $\mathrm{Li}$ and Gregory, 1974) and temperature gradients as $7^{\circ} \mathrm{C} / 100$ meters at Site 371 (estimated) and $2.6^{\circ} \mathrm{C} / 100$ meters at Site 374 (Erickson and Von Herzen, this volume). The following conclusions can be drawn. At Site 371 the observed concentrations agree with the model. This is also the case at Site 374 to approximately the depth of 360 meters. Evaporitic salts are found in Core $11(380 \mathrm{~m})$ and below. One can conclude that the agreement of the observations with the model predictions shows that formation factor data can be reliably used to predict diffusive profiles in sediments.

One should note that the concentrations of chemical species whose distributions between two boundaries are controlled by diffusion and sedimentation will plot on a straight line. Further, the concentration of a species that is either produced or consumed between the boundaries, when plotted against that of a species controlled by physical processes alone, will show deviation from linearity (Craig, 1969). Consequently, at Sites 371 and 374, important information on the significance of chemical reaction can be gained by considering plots of various species versus chloride, since we have demonstrated that chloride is conservative.

\section{Diagenesis}

A general characteristic of Leg $42 \mathrm{~A}$ sites is their rapid rate of sedimentation. In general, faster deposi- 
TABLE 1

Interstitial Water Data, Leg 42A

\begin{tabular}{|c|c|c|c|c|c|c|c|c|c|c|c|c|}
\hline Section & $\begin{array}{c}\text { Depth } \\
\text { (m) }\end{array}$ & $\begin{array}{c}\mathrm{Na} \\
\mathrm{mmole} / 1\end{array}$ & $\underset{\text { mmole/l }}{\mathrm{K}}$ & $\underset{\mathrm{mmole} / \mathrm{l}}{\mathrm{mg}}$ & $\begin{array}{c}\mathrm{Ca} \\
\mathrm{mmole} / 1\end{array}$ & $\begin{array}{c}\mathrm{Sr} \\
\text { mmole/I }\end{array}$ & $\begin{array}{c}\mathrm{Cl} \\
\text { mmole/I }\end{array}$ & $\begin{array}{c}\mathrm{SO}_{4} \\
\text { mmole/1 }\end{array}$ & $\begin{array}{c}\text { Alk } \\
\text { meq } / 1\end{array}$ & $p \mathrm{H}$ & $\underset{\text { mmole/1 }}{\mathrm{NH}_{4}}$ & $\begin{array}{c}\text { Si } \\
\text { mmole }\end{array}$ \\
\hline \multicolumn{13}{|l|}{ Site 371} \\
\hline $1-5$ & 8 & - & - & 63.5 & 13.4 & 0.20 & 647 & 26.5 & 3.58 & 6.9 & 590 & 130 \\
\hline $2-2$ & 207 & - & - & 194. & 208. & 2.7 & 1670 & 7.9 & 0.63 & 6.0 & 1430 & 96 \\
\hline $3-5$ & 369 & - & - & 273. & 317. & 3.8 & 2210 & 5.6 & 0.57 & 8.2 & 970 & 130 \\
\hline $4-5$ & 407 & - & - & 456. & 509. & 4.4 & 2910 & 8.8 & 0.55 & 6.2 & 1180 & 75 \\
\hline $5-5$ & 464 & - & - & 653. & 656. & 5.9 & 3680 & 5.0 & 0.57 & 5.8 & 540 & 57 \\
\hline $8-2^{a}$ & 549 & - & - & 1280. & 960. & 14.9 & 4930 & 23.6 & 2.91 & 5.3 & 1490 & 51 \\
\hline
\end{tabular}

Site 372

\begin{tabular}{|c|c|c|c|c|c|c|c|c|c|c|c|c|}
\hline $1-3$ & 120 & - & - & 77.6 & 33.5 & 0.60 & 866 & 33.5 & 2.37 & 6.8 & 1910 & 180 \\
\hline $2-3$ & 139 & 744 & 7.5 & 74.5 & 45.2 & 0.69 & 915 & 37.6 & 1.61 & 6.8 & 1680 & 190 \\
\hline $3-2$ & 148 & 745 & 8.4 & 75.6 & 49.9 & 0.68 & 924 & 40.2 & 1.36 & 6.9 & 1740 & 170 \\
\hline $9-3$ & 203 & 958 & 8.9 & 85.4 & 79.8 & 1.1 & 1230 & 34.1 & 1.13 & 6.8 & 3250 & 310 \\
\hline $14-4$ & 251 & 980 & 8.5 & 70.1 & 67.3 & 1.8 & 1230 & 18.0 & 0.75 & 7.1 & 3350 & 150 \\
\hline $19-4$ & 299 & 1010 & 7.3 & 57.7 & 74.1 & 2.4 & 1270 & 9.3 & 0.58 & 7.5 & 3540 & 150 \\
\hline $24-5$ & 348 & 1140 & 7.5 & 59.5 & 74.1 & 2.6 & 1400 & 7.5 & 0.76 & 6.9 & 3690 & 200 \\
\hline $29-4$ & 395 & 1380 & 7.8 & 63.0 & 93.7 & 2.7 & 1690 & 6.8 & 0.74 & 7.2 & 3930 & 420 \\
\hline $33-5$ & 471 & 1320 & 6.7 & 67.1 & 97.6 & 2.4 & 1650 & 5.0 & 0.86 & 7.0 & 4100 & 360 \\
\hline $36-5$ & 579 & 1480 & 7.5 & 67.7 & 111. & 2.4 & 1840 & 5.9 & 0.88 & 7.0 & 2820 & 430 \\
\hline
\end{tabular}

Site 374

\begin{tabular}{|c|c|c|c|c|c|c|c|c|c|c|c|c|}
\hline $2-2$ & 160 & 773 & 8.9 & 92.6 & 16.6 & 0.34 & 986 & 5.8 & 3.70 & 7.6 & 2100 & 210 \\
\hline $4-3$ & 255 & 986 & 14.0 & 527. & 127. & 1.4 & 2260 & 25.2 & 0.89 & 5.5 & - & 94 \\
\hline $5-4$ & 302 & 1020 & 31.0 & 1160. & 253. & 2.3 & 3850 & 13.3 & 0.41 & 4.9 & 1170 & 86 \\
\hline $6-1$ & 322 & 860 & 44.0 & 1030 . & 342. & 2.1 & 3630 & 9.4 & 0.34 & 4.8 & 750 & 69 \\
\hline $6-5$ & 338 & 770 & 49.0 & 1060 . & 354. & 2.1 & 3620 & 14.6 & 0.35 & 5.1 & 660 & 77 \\
\hline $7-1$ & 342 & - & 48.0 & 1340 . & 466. & 2.3 & 4400 & 13.2 & 1.56 & 6.0 & 2300 & 100 \\
\hline $7-3$ & 345 & 632 & 44.0 & 1380 . & 472. & 2.2 & 4350 & 16.3 & $\sim 1.5$ & - & 1710 & 100 \\
\hline $7-4$ & 346 & 726 & 44.0 & 1370 . & 480 . & 2.3 & 4450 & 11.2 & 1.72 & 5.6 & 1630 & 120 \\
\hline $7-6$ & 350 & 714 & 57.0 & 1360 . & 470 . & 2.2 & 4380 & 26.8 & 1.62 & 6.0 & 1740 & 100 \\
\hline $8-2$ & 356 & 686 & 48.0 & 1320 . & 431 . & $\begin{array}{l}2.2 \\
2.0\end{array}$ & 4170 & $\begin{array}{l}20.0 \\
34.2\end{array}$ & $\begin{array}{l}1.02 \\
2.03\end{array}$ & 6.0 & 1740 & 85 \\
\hline $9-3$ & 367 & (539) & 68.0 & 1600. & 454. & $\begin{array}{l}2.0 \\
2.0\end{array}$ & 4690 & $(13.2)$ & 2.97 & 5.9 & 2340 & 52 \\
\hline $11-2(22 \mathrm{~cm})^{b}$ & 378 & - & - & 1940. & 300 . & - & 4740 & 26.4 & - & - & - & - \\
\hline $11-2(86 \mathrm{~cm})^{b}$ & 381 & - & - & 2150 . & 286. & - & 4620 & (21.9) & - & - & 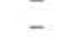 & 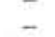 \\
\hline $12-1^{b}$ & 383 & - & - & 2210 . & 176. & - & $\begin{array}{l}4020 \\
4730\end{array}$ & 41.6 & - & - & 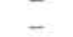 & - \\
\hline $12-2^{b}$ & 385 & - & - & 2280 . & 87.0 & - & 4770 & 44.6 & - & - & - & - \\
\hline $13-1$ & 389 & 519 & 40.0 & 2140 . & 24.1 & 0.30 & 4790 & 47.2 & 3.42 & 5.6 & 2000 & 110 \\
\hline $14-1$ & 395 & 572 & 43.0 & 2250 . & 9.7 & 0.16 & 4950 & 90.0 & 4.86 & 5.3 & 1770 & 130 \\
\hline $15-1$ & 405 & 640 & 49.0 & 2250 . & 9.7 & 0.14 & 5020 & 95.8 & 4.90 & 5.3 & 1350 & 190 \\
\hline
\end{tabular}

Site 375

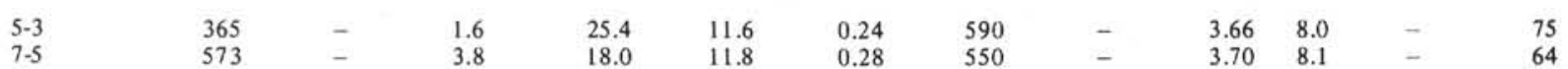

Site 376

\begin{tabular}{|c|c|c|c|c|c|c|c|c|c|c|c|c|}
\hline $1-4$ & 6 & - & 10.2 & 57.3 & 9.9 & 0.14 & 614 & - & - & 8.0 & - & 330 \\
\hline $5-4$ & 44 & - & 8.6 & 54.9 & 10.7 & 0.16 & 608 & - & 3.02 & 7.7 & - & 150 \\
\hline $9-3$ & 82 & - & 7.3 & 55.5 & 15.4 & 0.18 & 604 & - & 1.44 & 7.6 & - & 310 \\
\hline $12-3$ & 109 & - & 8.5 & 52.9 & 23.1 & 0.20 & 599 & - & 1.27 & 7.6 & - & 500 \\
\hline $13-2$ & 118 & - & 7.4 & 53.7 & 26.3 & 0.22 & 601 & - & 1.33 & 7.7 & - & 530 \\
\hline $15-2$ & 129 & - & 7.8 & 56.6 & 36.3 & 0.37 & 629 & - & 0.61 & 7.8 & - & 190 \\
\hline
\end{tabular}

Site 377

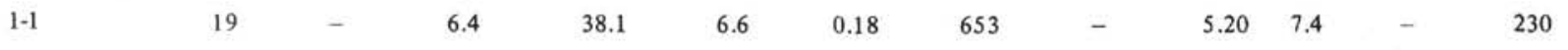

Site 378

\begin{tabular}{|c|c|c|c|c|c|c|c|c|c|c|c|c|}
\hline 1.2 & 92 & 531 & 7.7 & 34.7 & 9.9 & 0.64 & 606 & 10.0 & 3.32 & 7.5 & - & 360 \\
\hline $5-1$ & 130 & 542 & 7.0 & 35.9 & 12.2 & 0.69 & 614 & 14.6 & 3.40 & 7.3 & - & 760 \\
\hline $7-4$ & 177 & 523 & 6.6 & 35.4 & 13.8 & 0.77 & 604 & 11.7 & 1.87 & 7.5 & - & 530 \\
\hline $8-1$ & 224 & 524 & 6.6 & 35.4 & 14.0 & 0.79 & 604 & 12.2 & 2.62 & 7.2 & - & 970 \\
\hline $11-3$ & 310 & 526 & 7.3 & 42.1 & 38.3 & 0.51 & 604 & 45.0 & 0.62 & 7.6 & - & 190 \\
\hline
\end{tabular}

Site $378 \mathrm{~A}$

\begin{tabular}{rrrrrrrrrrrrr}
$1-2$ & 51 & 557 & 8.5 & 36.0 & 6.8 & 0.33 & 616 & 15.7 & 4.13 & 7.5 & - & 360 \\
$3-5$ & 300 & 536 & 8.5 & 41.6 & 38.3 & 0.50 & 616 & 44.2 & 0.63 & 7.7 & - & 150 \\
\hline
\end{tabular}

Note: Values in parentheses are questionable.

${ }_{b}^{\mathrm{a}}$ Shipboard $\mathrm{Ca}, \mathrm{Mg}$ in error

Squeezed from stored sediment 

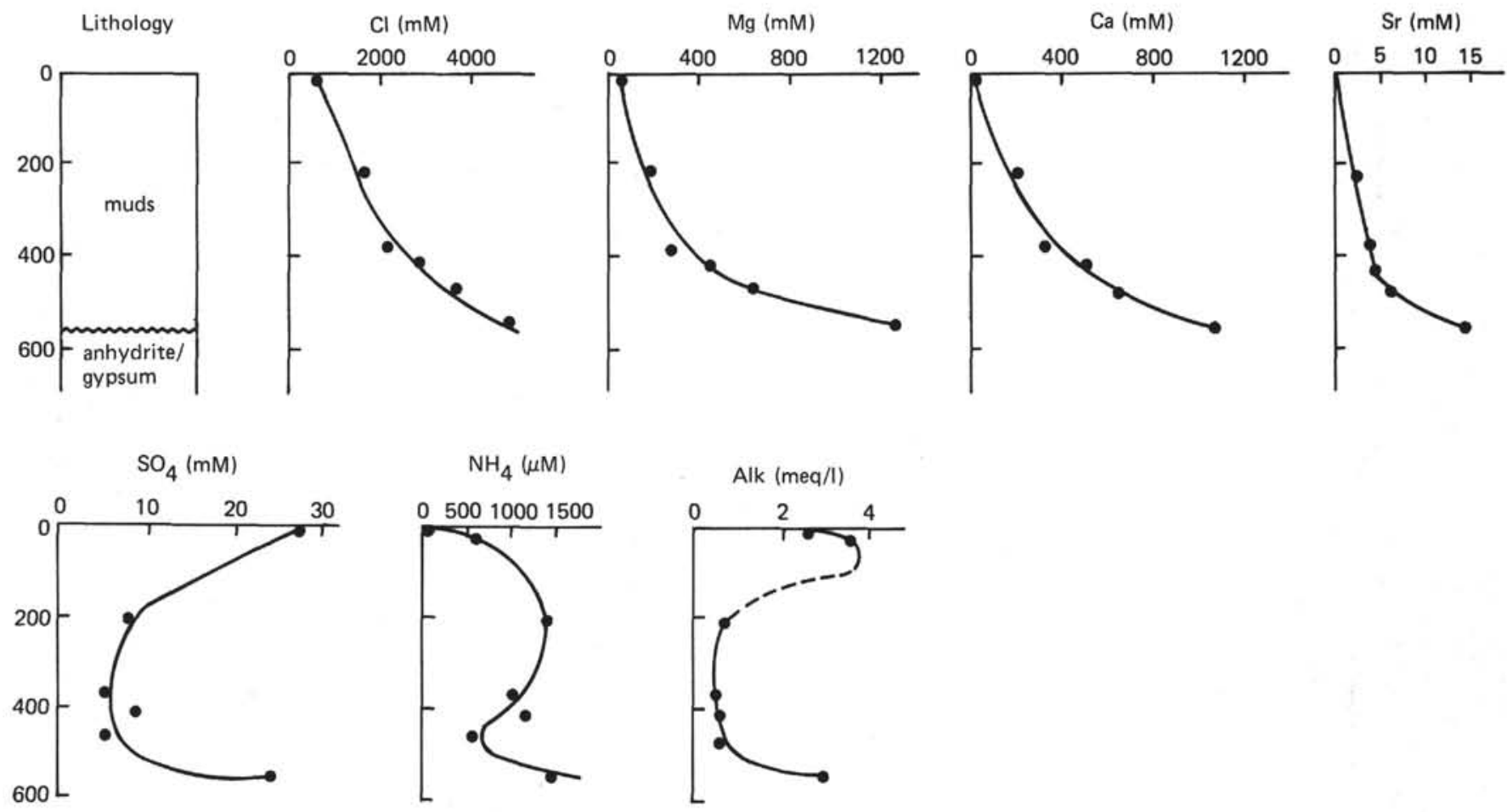

Figure 1. Interstitial water profiles, Site 371.
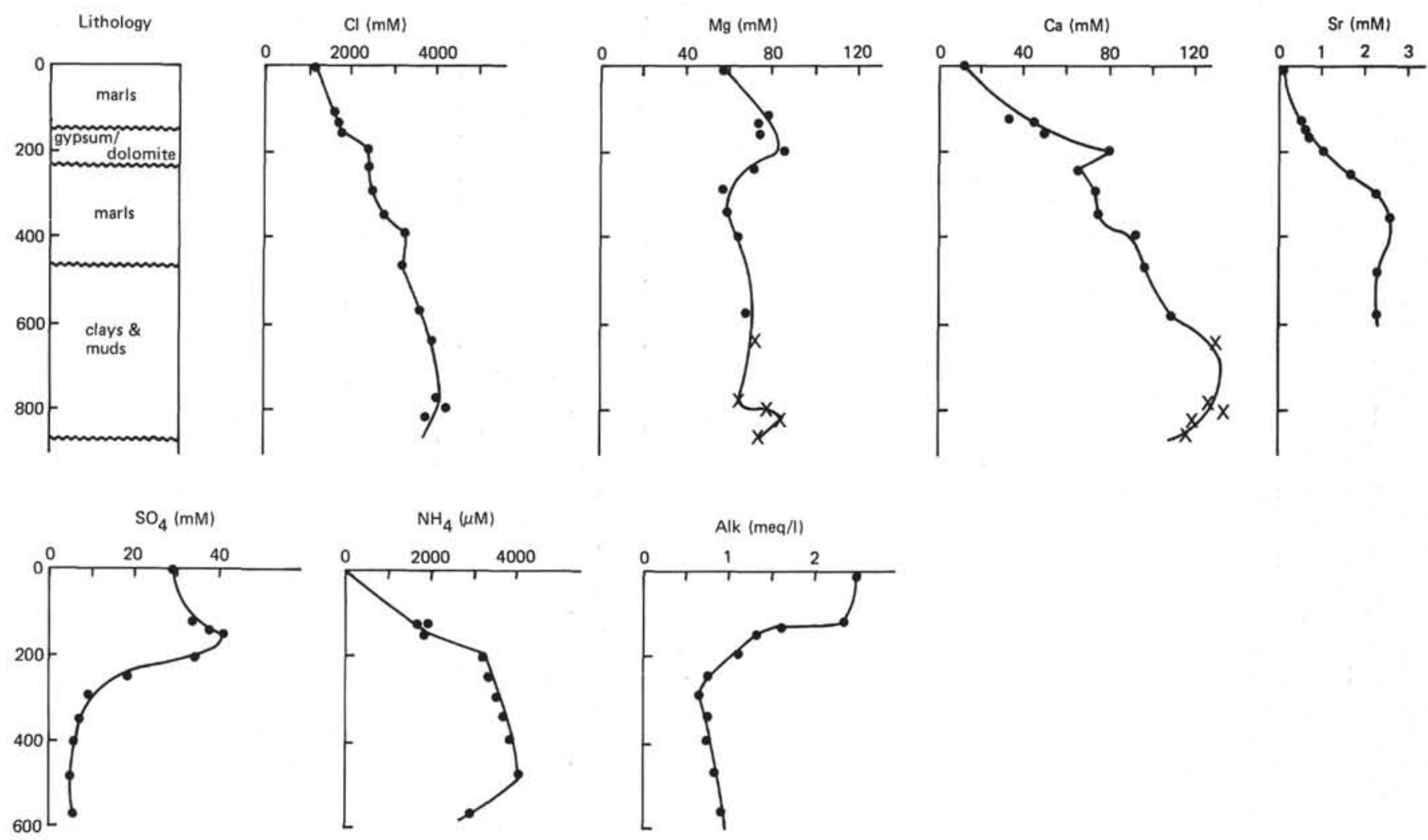

Figure 2. Interstitial water profiles, Site 372. The symbol $\bullet$ denotes values from Table 1 , and $\mathrm{X}$ denotes uncorrected shipboard values (see text).

tion, whether or not accompanied by high organic content, leads to depletion of dissolved sulfate and enrichment of dissolved ammonia (Gieskes, 1974; Gieskes and Lawrence, 1976). This is because diffusion away from the zone of reaction is not as fast as the rate of sedimentation, and thus the sediments are not in communication with the overlying water. These considerations are apparent in the dissolved ammonia data. 

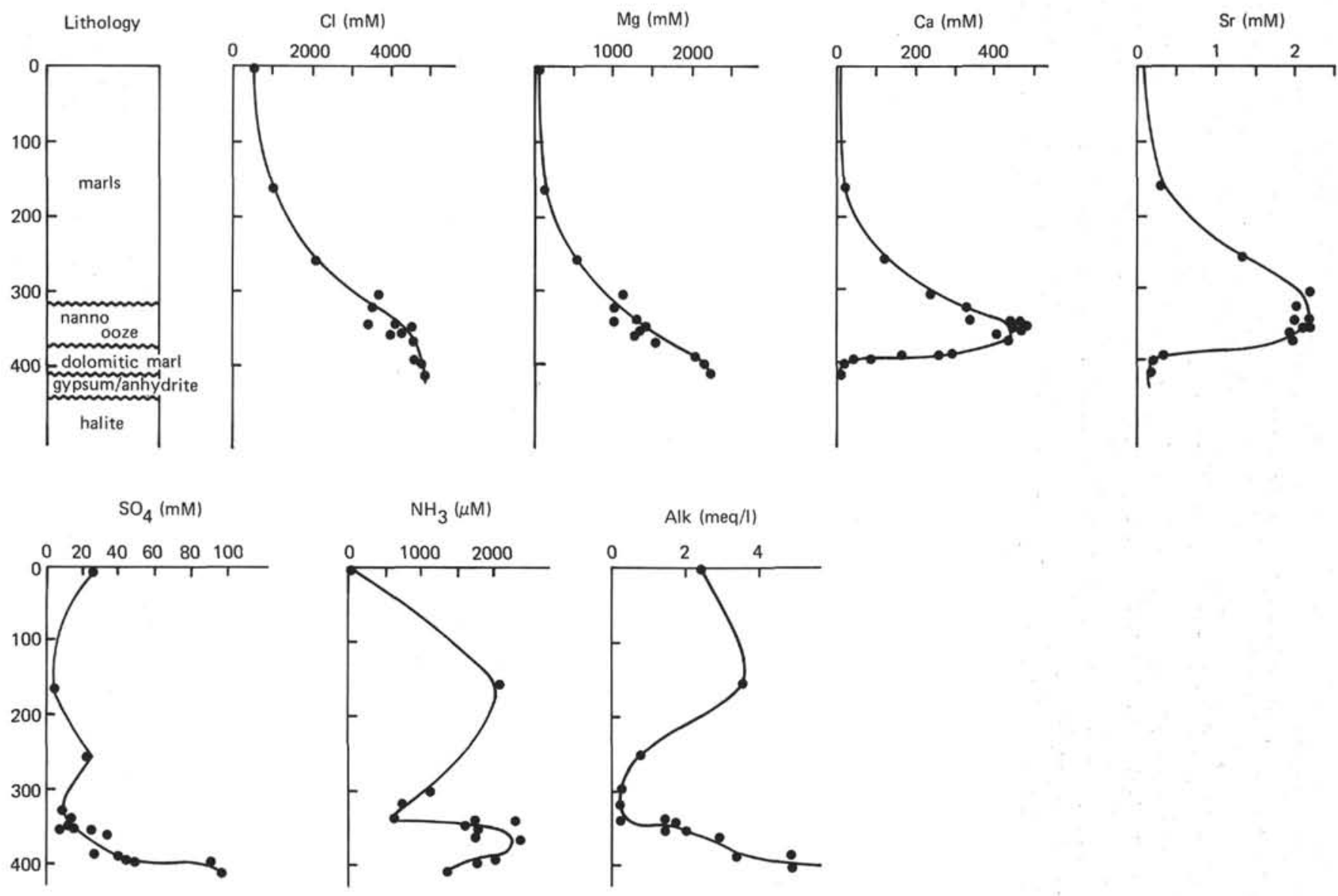

Figure 3. Interstitial water profiles, Site 374.

However, sulfate profiles are clearly influenced by a second process, dissolution of gypsum and/or anhydrite. Thus, the sulfate profiles are best understood in terms of reduction of sulfate oxidizing organic matter in addition to release of sulfate from evaporite phases. Thus at Sites 371 and 374 sulfate values are low until gypsum is reached at great depth, and at Site 372 sulfate shows a maximum due to the occurrence of gypsum in Cores 5-9.

The remaining components will be considered site by site.

\section{Site 371}

The divalent cations show an interesting contrast. Calcium plots linearly against chloride and therefore is conservative in the sediment column (Figure 5). Its probable source is calcium chloride salts in the region of the deepest sediments drilled. Perhaps a careful search would reveal this type of solid in the deepest sediments cored. Magnesium and strontium, however, show substantial depletion with respect to conservative behavior and thus are being removed in the sediment column. The depletion of alkalinity, despite clear evidence of sulfate reduction, is probably related to these removal processes, perhaps formation of magnesian calcite or dolomite. However, the magnitude of the deviation is too great for this to be the only process acting. Some other as yet unidentified reaction must be operative.

\section{Site 374}

As was discussed earlier, the distribution of chloride is controlled mainly by physical processes between 0 and 360 meters. Below this, there must be a chloride source. The lack of enrichment of sodium demonstrates that it is not from the halite found in Core 22 and presumably deeper. This is also borne out by the relative constancy of chloride below 360 meters. Indeed, the resistivity measurement in Core 374-17, Section 4 indicates the presence of an impermeable layer. We would suggest that this source is a chloride salt located in or below Core 11 .

\section{Site 372}

Sodium and chloride are linearly correlated, suggesting that they are both supplied by dissolution of evaporites located much below the deepest sediments drilled. However, because of insufficient data on the porosity minimum in the gypsum layers in Cores 5-9, we were unable to apply a diffusion model to verify this.

The alkaline earths do not correlate with chloride but, instead, follow a complicated curve, suggesting involvement in a variety of diagenetic reactions pro- 
TABLE 2

Physical Properties, Leg 42A

\begin{tabular}{cccccc}
\hline & $\begin{array}{c}\mathrm{R}_{\mathrm{b}} \\
\text { Section }\end{array}$ & $\begin{array}{c}\mathrm{R}_{\mathrm{p}} \\
\left(\mathrm{ohm} \mathrm{cm}_{\mathrm{b}}\right)\end{array}$ & $\begin{array}{c}\mathrm{F} \\
\left.\text { (ohm } \mathrm{cm}_{\mathrm{p}}\right)\end{array}$ & $\begin{array}{c}\text { Water } \\
\left(\mathrm{cm}_{\mathrm{b}} \mathrm{cm}_{\mathrm{p}}{ }^{-1}\right)\end{array}$ & $\begin{array}{c}\text { Po- } \\
\text { Content }\end{array}$ \\
rosity \\
\hline
\end{tabular}

Site 371

$\begin{array}{rrr}1-3 & 58.6 & 25.9 \\ 1-5 & 67.7 & 25.9 \\ 2-2 & 53.0 & 10.5 \\ 2-3 & 47.3 & 10.5 \\ 3-2 & 48.9 & 8.5 \\ 3-5 & 56.2 & 8.5 \\ 4-4 & 47.3 & 7.5 \\ 5-4 & 53.0 & 6.5 \\ 8-2 & 3230 & 5.5\end{array}$

Site 372

$\begin{array}{lccccc}1-2 & 69.3 & 19.4 & 3.6 & 0.30 & 0.53 \\ 2-4 & 74.2 & 18.2 & 4.1 & 0.28 & 0.50 \\ 3-2 & 71.7 & 18.0 & 4.0 & 0.28 & 0.51 \\ 3-3 & 80.6 & 18.0 & 4.5 & 0.27 & 0.50 \\ 4-1 & 97.8 & 18.0 & 5.5 & 0.23 & 0.44 \\ 8-2 & - & - & - & 0.16 & 0.33 \\ 9-4 & 102 . & 13.9 & 7.3 & 0.23 & 0.44 \\ 11-2 & 76.6 & 13.9 & 5.5 & 0.25 & 0.46 \\ 18-6 & 94.6 & 13.7 & 6.9 & 0.25 & 0.47 \\ 27-4 & 134 . & 11.3 & 11.9 & 0.15 & 0.31 \\ 32-5 & 138 . & 10.3 & 13.3 & 0.16 & 0.33 \\ 34-4 & 104 . & 9.9 & 10.4 & 0.22 & 0.42 \\ 37-3 & 111 . & 8.9 & 12.5 & 0.16 & 0.33 \\ 39-3 & 126 . & 9.5 & 13.3 & 0.17 & 0.35 \\ 41-2 & 122 . & 8.7 & 14.1 & 0.17 & 0.35 \\ 44-4 & 122 . & 8.7 & 14.0 & 0.17 & 0.35\end{array}$

Site 374

$\begin{array}{lrrrrr}2-2 & 80.6 & 16.4 & 4.9 & 0.29 & 0.52 \\ 5-2 & 36.6 & 6.3 & 5.8 & 0.25 & 0.46 \\ 6-4 & 39.0 & 6.7 & 5.9 & 0.24 & 0.45 \\ 7-5 & 37.4 & 5.9 & 6.4 & 0.21 & 0.42 \\ 9-3 & 41.6 & 5.5 & 7.5 & 0.20 & 0.39 \\ 11-1 & 44.1 & 5.7 & 7.9 & 0.20 & 0.39 \\ 13-1 & 61.0 & 5.5 & 11.1 & 0.24 & 0.45 \\ 13-3 & 48.9 & 5.5 & 8.9 & 0.25 & 0.47 \\ 14-2 & 67.7 & 5.5 & 12.6 & 0.19 & 0.38 \\ 17-1 & >3300 & - & - & - & -\end{array}$

Site 376

\begin{tabular}{llllll}
$1-3$ & 66.9 & 26.9 & 2.5 & 0.37 & 0.61 \\
$3-3$ & 89.5 & 27.1 & 3.3 & 0.34 & 0.58 \\
$5-5$ & 85.5 & 27.1 & 3.2 & 0.34 & 0.57 \\
$9-4$ & 130. & 27.3 & 4.8 & 0.22 & 0.42 \\
$12-4$ & 130. & 27.5 & 4.7 & 0.26 & 0.48 \\
$16-1$ & 155. & 26.5 & 5.9 & 0.25 & 0.47 \\
\hline
\end{tabular}

Note: All measurements are at $4 \pm 1^{\circ} \mathrm{C}$ and are corrected for the appropriate cell constant. Water contents are from wet weight/dry weight measurements. Porosities are calculated assuming grain density of $2.6 \mathrm{~g} \mathrm{~cm}^{-3}$.

ceeding at different rates. The gypsum and dolomite layers in Cores 5-9 appear to serve as sources for calcium and magnesium, presumably due to dissolution of sulfates and/or associated dolomite. Below this horizon, there appears to be a sink for magnesium which is perhaps located in the carbonates and related to the depletion of alkalinity. Dissolved strontium exhibits a maximum at 350 meters which may be related to carbonate recrystallization processes. We cannot preclude the possibility of some supply of
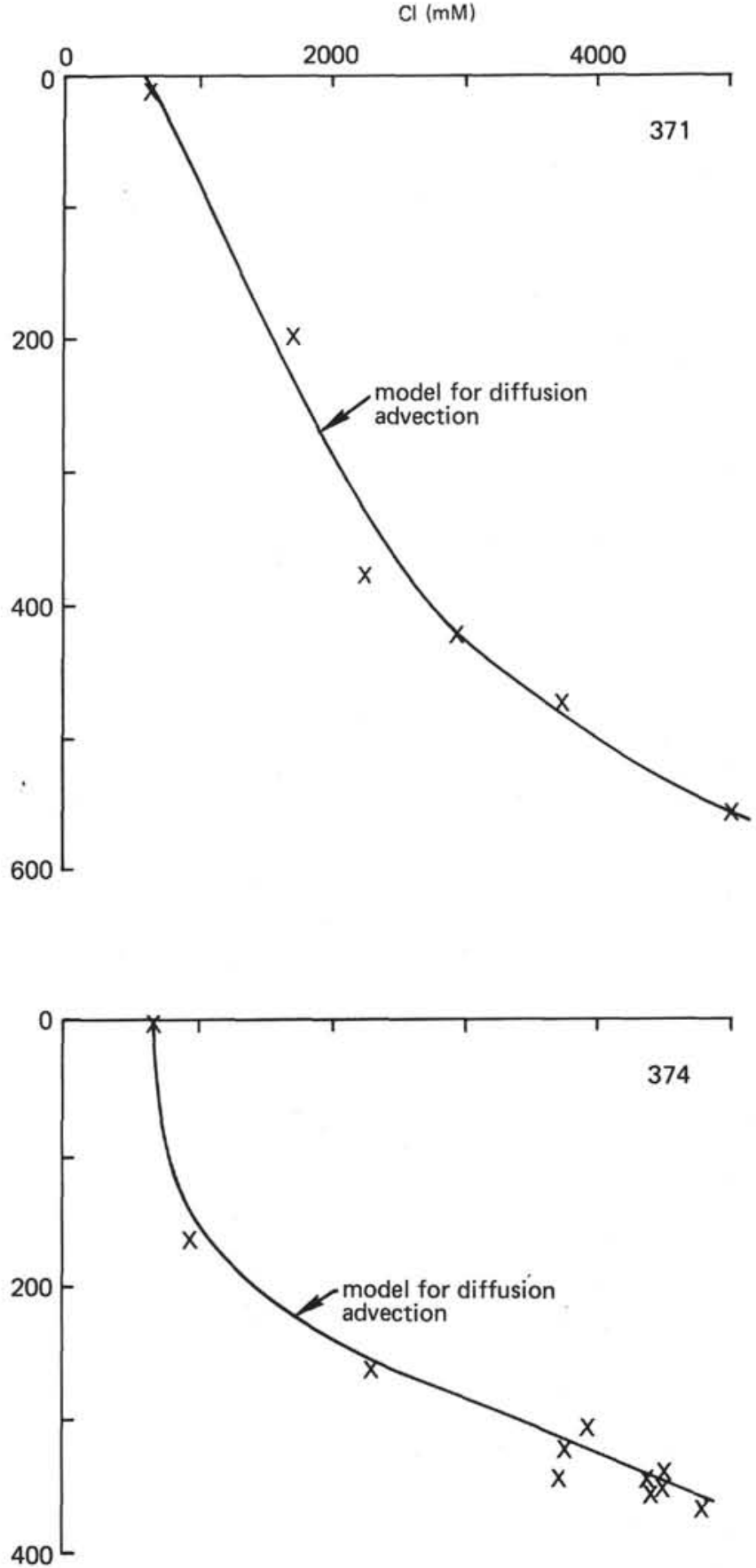

Figure 4. Comparison of profile calculated with model for diffusion and observed chloride values, Sites 371 and 374. Conditions as stated in text.

calcium and magnesium from evaporites at the same location as the source of sodium and chloride.

Magnesium is conservative to 360 meters and then shows marked enrichment relative to chloride; there seems to be a significant source below 360 meters. Calcium, on the other hand, shows production above 360 meters but then drops markedly to close to seawater values. We have verified that this change occurs smoothly; it is not possible that the gypsum layers in Core 11 Section 2 are acting as a diffusive 
barrier. This is evident in the profiles of $\mathrm{Ca}^{+2}, \mathrm{Mg}^{+2}$, $\mathrm{SO}_{4}^{-2}$, and Alk. In addition, there was no sign of a high formation factor in this interval. In this region, $\mathrm{SO}_{4}$ is greatly enriched, presumably due to gypsum dissolution, so that calcium is being added. Thus we require a sink not only for the calcium diffusing in, due to the sharp gradient, but also for the calcium derived from the gypsum. Alkalinity could be produced by sulfate reduction; however, an anomalously high ammonia value would have to be observed if this were serving to precipitate calcium in addition to supporting the sharp alkalinity gradient. However, the gradients are indicative of such large fluxes that study of the solids should lead to positive identification of the responsible phases. In any case, the high magnesium concentration, coupled with some enhancement of $\mathrm{PO}_{4}$ due to $\mathrm{SO}_{4}$

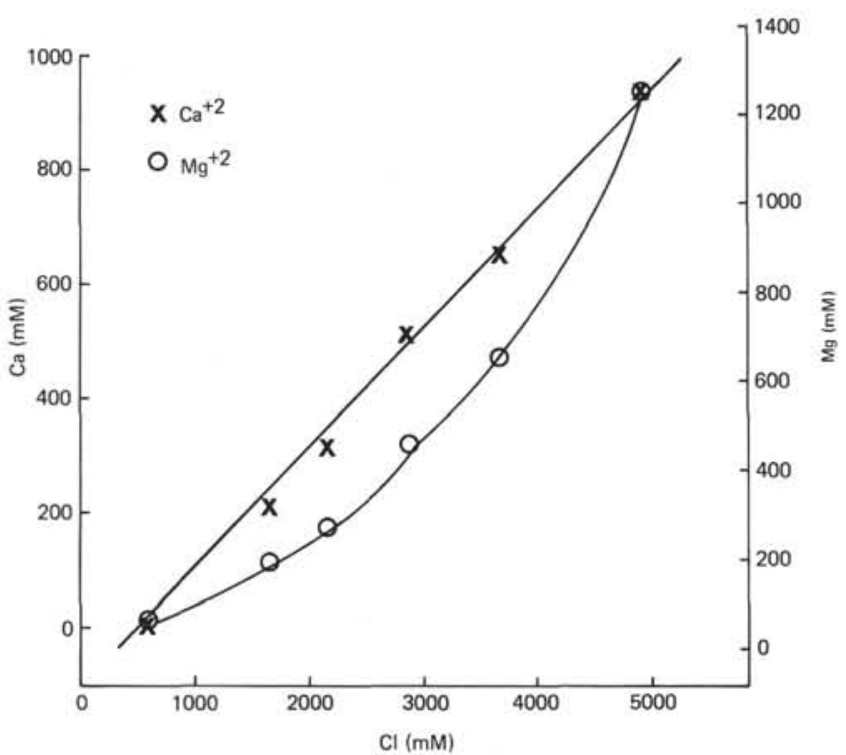

Figure 5. Calcium and magnesium versus chloride, Site 371.

The linearity of calcium profile is indicative of conservative behavior, while the deviation of magnesium profile indicates removal of magnesium in the sediment column.

reduction (reflected in alkalinity), could perhaps lead to the occurrence of the Mg-phosphate balls. We plan some $\mathrm{PO}_{4}$ measurements in the near future to follow this up.

\section{OXYGEN ISOTOPE DATA}

Analyses of the ${ }^{18} \mathrm{O} /{ }^{16} \mathrm{O}$ ratio of the interstitial waters (Table 3 ) show a very slight decrease with respect to present-day Mediterranean bottom water $\left(\delta^{18} \mathrm{O}=+1.0\right.$ to +1.5$)$. Sites 371 and 374 show very slight decreases, whereas the interstitial waters of Site 372 are slightly enriched in $\mathrm{O}^{18}$. Apparently the underlying evaporites have little or no influence on the oxygen isotope composition of the pore fluids.

\section{ACKNOWLEDGMENTS}

We thank Mr. Vic Sotelo, the shipboard chemist, for his careful determinations of alkalinity, $p \mathrm{H}$, calcium, and magnesium. Mr. Guntwin Galleisky kindly performed many of the sulfate determinations. Drs. Kenneth Hsü and Frank
TABLE 3

Oxygen Isotope Analyses of Interstitial Waters

\begin{tabular}{lll}
\hline Section & Depth $(\mathrm{m})$ & $\delta \mathrm{O}^{18}$ (SMOW) \\
\hline
\end{tabular}

Site 371

$\begin{array}{lrl}1-5 & 8 & +1.1 \pm 0.1 \\ 2-2 & 207 & +0.3 \pm 0.4 \\ 3-5 & 369 & +0.3 \pm 0.4 \\ 5-5 & 464 & +0.7^{\mathrm{a}} \\ 8-2 & 549 & -0.5 \pm 0.5\end{array}$

Site 372

$\begin{array}{rll}3-2 & 148 & +1.6 \pm 0.2 \\ 19-4 & 299 & +2.6 \pm 0.2 \\ 33-5 & 471 & +2.5 \pm 0.3 \\ 38-3 & 649 & +3.0 \pm 0.2 \\ 44-5 & 841 & +2.3 \pm 0.2\end{array}$

Site 374

\begin{tabular}{rll}
$2-2$ & 160 & $+1.3^{\mathrm{a}}$ \\
$4-3$ & 255 & $+1.1^{\mathrm{a}}$ \\
$5-4$ & 302 & $+0.9^{\mathrm{a}}$ \\
$7-2$ & 344 & $+0.8^{\mathrm{a}}$ \\
$13-3$ & 390 & $+0.9^{\mathrm{a}}$ \\
\hline
\end{tabular}

${ }^{\mathrm{a}}$ No duplicates available.

Fabricius reviewed the manuscript. This work was supported by grants from the National Science Foundation: DES 72 01410 (JMG) and OCE 75-02968 (JRL).

\section{REFERENCES}

Craig, H., 1969. Abyssal carbon and radiocarbon in the Pacific: J. Geophys. Res., v. 74, p. 5491-5506.

Epstein, S. and Mayeda, T., 1953. Variations in the $\mathrm{O}^{18}$ content of water from natural sources: Geochim. Cosmochim. Acta, v. 4, p. 213.

Gieskes, J. M., 1974. Interstitial water studies, Leg 25. In Simpson, E.S.W., Schlich, R., et al., Initial Reports of the Deep Sea Drilling Project, Volume 25: Washington, (U. S. Govt. Printing Office) p. 361-394.

1975. Chemistry of interstitial waters of marine sediments: Ann. Rev. Earth Planet. Sci., v. 3, p. 433-453.

Gieskes, J. M., and Lawrence, J. R., 1976. Interstitial water studies, Leg 35. In Hollister, C. D., et al., Initial Reports of the Deep Sea Drilling Project, Volume 35: Washington, (U.S. Government Printing Office), p. 407-424.

Gieskes, J. M., and Rogers, W. C., 1973. Alkalinity determination in interstitial waters of marine sediments: J. Sed. Petrol., v. 43, p. 272-277.

Imboden, D. M., 1975. Interstitial transport of solutes in non steady state accumulating and compacting sediments: Earth Planet. Sci. Lett., v. 27, p. 221-228.

Kastner, M. and Gieskes, J. M., 1976. Interstitial water profiles and sites of diagenetic reactions, Leg 35, DSDP, Bellings-hausen Abyssal Plain: Earth Planet. Sci. Lett., v. 33, p. $11-20$.

Li, Y. and Gregory, S., 1974. Diffusion of ions in seawater and in deep sea sediments. Geochim. Cosmochim. Acta, v. 38, p. 703-714.

Manheim, F. T., and Sayles, F. L., 1974. Composition and origin of interstitial waters of marine sediments, based on deep sea drill cores. In Goldberg, E. D., (ed.), The Sea, Vol. 5: New York (Wiley-Interscience), p. 527-568.

Manheim, F. T., and Waterman, L. S., 1974. Diffusimetry (diffusion coefficient estimation) on sediment cores by 
resistivity probe. In von der Borch, C. C., Sclater, J. G., et al., Initial Reports of the Deep Sea Drilling Project, Volume 22: Washington (U. S. Government Printing Office), p. 663-670.

Manheim, F. T., Waterman, L. S., Woo, C. C., and Sayles, F. L., 1974. Interstitial water studies on small core samples, Leg 23 (Red Sea). In Whitmarsh, R. B., Weser, O. E., Ross, D. A. et al., Initial Reports of the Deep Sea Drilling Project, Volume 23: Washington (U. S. Government Printing Office), p. 955-966.

McDuff, R. E. and Gieskes, J. M., 1976. Calcium and magnesium profiles in DSDP interstitial waters: Diffusion or reaction?: Earth Planet. Sci. Lett., v. 33, p. 1-10.
Sayles, F. L. and Manheim, F. T. (1975). Interstitial solutions and diagenesis in deeply buried marine sediments: Results from the Deep Sea Drilling Project: Geochim. Cosmochim. Acta, v. 39, p. 103-127.

Sayles, F. L., Waterman, L. S., and Manheim, F. T., 1972. Interstitial water studies on small core samples from the Mediterranean Sea. In Ryan, W. B. F., Hsü, K. J. et al., Initial Reports of the Deep Sea Drilling Project, Volume 13: Washington (U. S. Government Printing Office), p. 801-808.

Tsunogai, S., Nishimura, M., and Nakaya, S., 1968. Complexometric titration of calcium in the presence of large amounts of magnesium: Talanta, v. 15, p. 385-390. 